Journal of Engineering and Applied Sciences 14 (6): 1912-1921, 2019

ISSN: 1816-949X

(C) Medwell Journals, 2019

\title{
Evaluation of the Policy Implementation on Officers Recruitment at the Navy Information Service Using CIPP Model
}

\author{
Manahan Simorangkir, Maruf Akbar and Thomas Suyatno \\ Department of Human Resources Management, Jakarta State University (UNJ), Jakarta, Indonesia
}

\begin{abstract}
Aspects of context, input, process and product are very influential aspects of the policy implementation of officers personnel in the Navy information service. Variable identification and evaluation are necessary for the policy implementation. This study aims to evaluate the policy of officer recruitment in the Navy Information Service Department. The policy evaluation method used is the development of the CIPP method, there are context, input, process and product analysis. The identification of variables in the CIPP aspect has been done as an evaluation material including the interaction relationship between these aspects as a system. The output of the policy evaluation model is a thorough evaluation of the variables of needs, problems and objectives are as the component of evaluation on context aspect. The variables of human resources, finance, facilities and readiness are as the component of evaluation on input aspect. The variable of recruitment mechanism and obstacles are as the component of evaluation on process aspect. The variable of administrative standards and competency standards are as the component of evaluation on product aspect. The results obtained in this study is a strategic recommendation regarding the handling of professional and standardization of personnel who can serve in the field of Naval public affairs. This is an effort to ensure that the Navy's military enforcement service can be accurate, capable of human resources and resilient in carrying out the duties and responsibilities of the organization and able to achieve the vision of world class Naval public affairs.
\end{abstract}

Key words: Policy implementation, CIPP evaluation model, Navy information service, human resources, finance, enforcement

\section{INTRODUCTION}

In an organization of the Navy, Human Resource Development (HRD) is a top priority because today not only as a means of production but also as a driving force and determinant of the operational process and all activities of the Navy. HRD has a major role in determining the advance or development of the Navy. Therefore, the progress of the Navy organization is determined by the quality and capability of human resource development.

Human resource management is one of the business needs today. Human resource management departments have a very important role to supply humans to the company's main resources. The Human Resource Management Department has a fundamental role in personnel recruitment, orientation and performance appraisal and so on. The issue of human resource management should be addressed at the highest level within the organization and strategic decision management is required (Armstrong, 2009).

In relation to the importance of human resource development in the organization of the Navy, there is a work unit that has a role as a liaison between the Navy and the public through the media. In this unit, the role of human resources is vital because the tasks and responsibilities are directly related to the publication and information about the Navy and the Naval forces and have an important role in shaping public and regional opinion and understanding, both regionally and internationally. The work unit is the Navy information service. Navy information service is part of the organization of the Navy. The Navy information service has the vision to become world class naval public affairs.

In order to execute these tasks and carry out his vision, Navy information service is in need of skilled personnel and mastering the field of duty well. As an officer serving in the information service must have a standard of knowledge and capability as an information personnel, so that, the information service can always perform its duties with professionals. An officer is always in a position as a manager who must be able to manage human resources in his work unit and master the field of work. An officer serving in Navy information service must

Corresponding Author: Manahan Simorangkir, Department of Human Resources Management, Jakarta State University (UNJ), Jakarta, Indonesia 
be able to become a reliable public relation. For this reason, recruitment of officers for the field of information serving should be in accordance with the needs in the ability and knowledge because the scope of the task field is very varied and the ability in managing human resources. Thus, the recruitment of officers in the field of information greatly affects the performance of the information service.

Some problems that occur today, if viewed from aspects of context, aspects of input, aspects of the process and aspects of the product are as follows:

Aspect of context: Is the policy of the Navy on personnel recruitment programs for officers, especially, in the Navy information service work unit a necessity for the organization?

Has the recruitment process that has been carried out specifically to obtain officers capable of being deployed and serving in the Navy has been able to be considered capable of meeting the needs of personnel according to DSP, organization, expertise and field of duty? What can be the diagnosis of the problems that behind the needs of the information officer?

Can this recruitment program be seen to support the achievement of work unit programs even towards the achievement and implementation of the vision of the Navy?

Aspect of input: How does the Navy information service do in preparation for the implementation of the recruitment process from the human resources side, readiness and budget? How is the availability of facilities to support the recruitment program?

What is the readiness of the recruitment mechanism from the administration side and the side of the procedure?

Aspects of process: How is the officer recruitment process implemented for the Navy information service? What are the barriers that can happen to the recruitment process?

Aspects of product: How does the recruitment result be viewed from the standpoint of standard administration and competency standards?

How is the recruitment product, especially, perceived Navy information service as the user of recruitment related to the effort to carry out the main task of Navy information service according to the mission and vision of the organization in order to realize the vision of the Navy?

In general, the focus of this research is "Evaluate on Policy Implementation of Officers Recruitment in Navy information service". Which will be elaborated through the CIPP evaluation with various aspects that influence in terms of context, input, process, output and product, whereas in particular, the focus of this research is on evaluation:

Policies or rules or provisions which became the basis for the recruitment of officers at the Navy information service.

Recruitment policy is an effort undertaken by the recruitment department in order to seek or select qualified personnel and officers of officers in the Navy's professional and qualified Naval information office. Recruitment has a very close relationship with existing regulations or policies or provisions. The implementation of recruitment at this time will greatly affect the composition of personnel officers with qualified on the organization of the Navy.

In the end, a strategic recommendation will be made regarding the professional handling and standardization of personnel who can serve in the field of the information service. It is intended that the Navy information service can be accurate, capable and resilient in carrying out the duties and responsibilities of the organization and achieve the vision of world class naval public affairs.

Furthermore, this study aims to determine the extent to which the application of regulations and procedures in the recruitment of personnel officers in the Navy information service, so that, the human resources owned by the Navy in this qualification can be met properly. Another goal is to obtain theoretical evidence and field experience in order to improve human resources.

\section{MATERIALS AND METHODS}

The concept of policy evaluation: The definition of evaluation is contained in the Oxford Advanced Learner's Dictionary of Current English which refers to the evaluation as to find out, the decision of the amount or value which means an attempt to determine the value or amount. Policy evaluation can be defined as a process carried out directly in the collection, analysis and interpretation of information or policy, so that, a conclusion about a data or research, value or significance of a program, project, policy or a thing is being tested. Thus, the output of an evaluation is the achievement of something favorable, such as development suggestions and direction for future activities. The policy evaluation can be applied to six evaluation approaches (Anyim et al., 2012), namely:

Goal-oriented evaluation; this evaluation is aimed at measuring the level of achievement of objectives in the implementation of programs or activities by the target group or measuring the results of program/activity implementation. 
User-oriented evaluation: This evaluation emphasizes the outcome or product which results that can meet expectations or satisfy the needs of users.

Skill-oriented evaluation: This evaluation uses a standard of expertise. It is directed at the evaluation of a program or component of the education component using criteria or standards that have been formulated by experts as a good program or component.

Decision-oriented evaluation: This evaluation is directed to the process of determining the types of decisions to be taken, the selection, collection and analysis of data needed for decision making and the delivery of results (reports) to decision makers.

An opponent-oriented evaluation: This evaluation uses different standards or criteria even in contrast to the standards used.

Evaluation oriented naturalistic participants: This evaluation is holistic using a variety of instruments and various data in order to obtain a complete understanding from different perspectives and values on the implementation of education from the perspective or point of view of the participants (Bryson, 1995).

Policy evaluation is always concerned with the policy implementation process. Implementation of policy is an activity that has 3 important and absolute element in running it (Tsolakis and Srai, 2017). The elements of policy implementation:

- The existence of programs implemented

- The existence of target groups, i.e., target communities and beneficiaries of the program

- The existence of implementation, whether the organization or individual responsible for the management, implementation and supervision of the implementation process

Implementation of policy is one of the stages in the public policy process. Implementation is implemented after a policy is formulated with clear objectives and subsequently evaluated. Implementation is a series of activities in order to deliver the policy to the community, so that, the policy can bring the results as expected. (Hasenfeld, 1983).

The concept of personnel recruitment: The concept of personnel recruitment by Kirkpatrick (1994) states that: "Recruitment and selection remains one of the most important functions of the Human Resources Department. As competition increases between firms, selecting and recruiting the right and qualified talents become all the more important".
Recruitment and selection remain one of the most important of Human Resources Department functions. As competition increases between companies, choosing and recruiting the right talent and qualified personnel is more important (Fitzpatrick et al., 2004).

The same is also expressed by the next researcher who states that: "Recruitment and selection in any organization or efficiency in service delivery depend on the quality of its workforce who was recruited into the organization through recruitment and selection exercises (Thornhill, 2009).

Youssefi et al. (2011) reported that it for managers to understand the objectives, policies and practices used for selection. More importantly, those responsible for making selection decisions should have adequate information upon which to base their decisions. As Sandfort (1999) observed, the resource policies and practices represent important forces in shaping employee behavior and attitudes. In view of the findings, the study suggests that in designing and instituting recruitment and selection criteria quality should not be compromised.

Based on some concept of recruitment definition of personnel, it can be said that every organization certainly need the concept of recruitment of the right personnel, this is because it very affects the performance of the organization. In the implementation of a work, the analysis should be able to provide good information with the aim to be able to support planning in the recruitment, selection and placement of personnel (Tiantong and Tongchin, 2013).

Recruitment activities personnel have a close relationship with the development of an organization's strategic plan but it must also be implemented internally consistently. Because it must be in line with the achievement of the vision of the organization and can be professionally and have a high performance in the execution of tasks (Zhang et al., 2011). Stages of recruitment and selection and relationship with human resource planning can be explained in Fig. 1.

Each division of personnel (Human resource management) must understand the types and qualifications that must be possessed by each personnel to occupy certain positions or positions within the organization. Because placing personnel in a position and position for the purpose of promotion, it would be easier if the details on the tasks and responsibilities and qualifications are well known and understood (Suharyo, 2017).

Recruitment and replacement of personnel should include three stages, the following: Identify and analyze key jobs, formulate job descriptions and specifications in the present and future. 


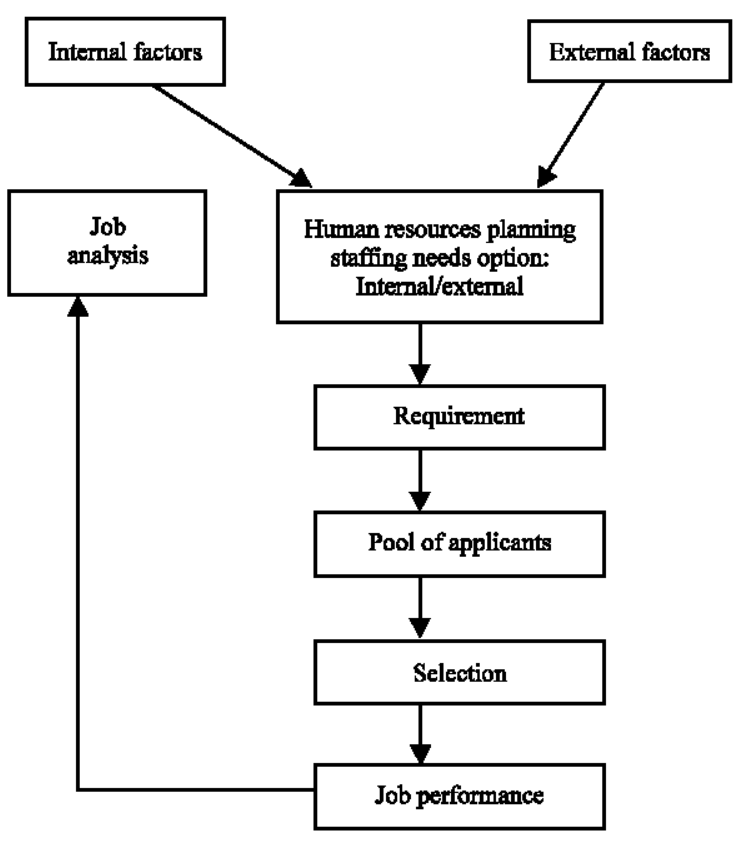

Fig. 1: Recruitment-selection stages and relationship with human resource planning

Creating and appraising prospective personnel by identifying internally and externally in order to become qualified personnel in such positions or strategic positions. It can look to internal training and cross-functional experience or through job rotation, external training/education and global/regional assignments.

Conducting selection to occupy the position or strategic position. Position and number appropriate to the needs of recruitment planning. Selection should be implemented gradually and in accordance with aspects considered important by the organization. The selection stage should be clear and understandable by all applicants who register.

CIPP evaluation model: This research develops and uses evaluation modeling with CIPP Model (Context, input, process, product), first introduced by Stufflebeam in 1969. The CIPP evaluation method can be understood as a systematic evaluation method which can be explained in Fig. 2. CIPP Model diagram as follows:

Context evaluation: Context evaluation is an attempt to describe and detail the environment, unmet needs, populations and samples served and the project objectives. Questions that can be asked in relation to the evaluation of the context are what needs have not been fulfilled by the program, unachievable development objectives and the easiest goals to achieve them. Further

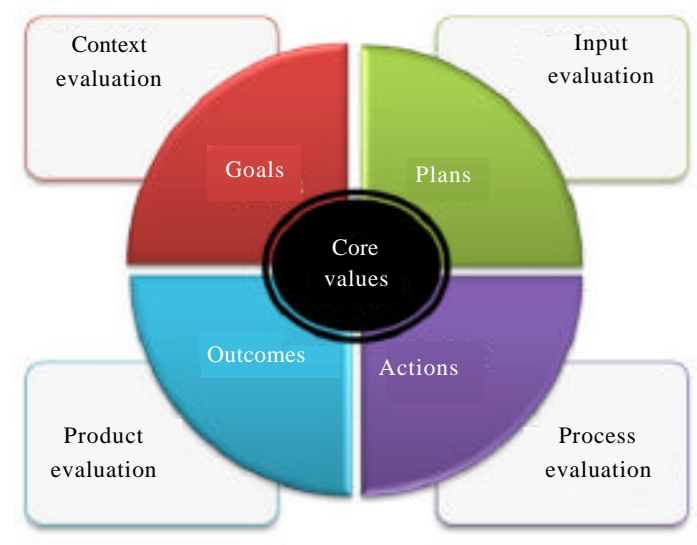

Fig. 2: CIPP Model diagram

relevant environmental conditions, description of existing and desired conditions as well as identifying needs for unmet needs and untapped opportunities. Evaluate unmet needs and untapped opportunities. This evaluation is also related to existing and new value systems, presenting tools for setting priorities as well as desired changes (Thornhill, 2009).

Input evaluation: Input evaluation is a program that provides data to determine how the source can be used to achieve program objectives. This evaluation includes the identification and assessment of system capabilities used in the program, strategies for achieving program objectives and the design of the implementation of the selected strategy. These input evaluations help organize decisions, determine what resources exist what alternatives are taken what plans and strategies to achieve needs and how the work procedures to achieve them (Aldaihani et al., 2015).

Process evaluation: The process evaluation in the CIPP Model refers to the "what" of the activities undertaken in the program "who" the person designated as the program responsible, "when" the activity will be completed. In the CIPP Model, process evaluation is directed to the extent to which activities implemented in the program have been carried out in accordance with the plan.

Stufflebeam (1983) raises questions that need to be answered in relation to the evaluation of this process, namely the implementation of programs that are in accordance with the schedule, the ability of the staff involved in the implementation of the program, the maximum utilization of the facilities and infrastructure provided and the constraints encountered during program implementation and possible program sustainability. The evaluation of this process detects and predicts 
shortcomings in the design of procedures for program activities and their implementation, provides data for decisions in program implementation and maintains documentation of the procedures undertaken. Documentation of the program implementation procedures will assist the final analysis of the results of the program.

Stufflebeam (1983) further states that process evaluation is used to assist in the implementation of decisions, the extent to which the plan is implemented and what plans require revisions. Once the question is answered, the procedure can be monitored, controlled and improved.

Product/results evaluation: The evaluation of a product or product is directed at the things that indicate the changes that occur in the raw input. Product evaluation is the final stage of a series of program evaluations. Evaluate the product to help the next decision. Stufflebeam (1983) poses questions regarding the evaluation of this product, namely the achievement of a defined goal or outcome, possible statements formulated between the details of the process and the achievement of the objectives, the individual needs that have been fulfilled and the long-term outcome (impact) as a result of program activities and on what to do after the process. Evaluate the program as a systematic activity to collect, process, analyze and present data as input for decision making. The product evaluation threshold contains three important elements:

Systematic activity: Implies that program evaluation is conducted through an orderly procedure based on scientific rules.

Data: The data collected as the focus of program evaluation is obtained through collection, processing, analysis and presentation using scientific approaches, models, methods and techniques.

Decision-making: The data presented will be valuable if it becomes a valuable input to the decision-making process about the alternatives to be taken against the program (Wei et al., 2011).

This research is aimed to get data, facts and information about Evaluation on Implementation of Officer Recruitment Policies in Navy information Unit by using CIPP Model, so that, in the end, it will be easy to detect any weakness of recruitment process that has been implemented.

Specifically, this research has the purpose of application and development on CIPP evaluation model which is used to:
- To evaluate the achievement of the objectives of recruitment of officers Navy information service

- To evaluate the readiness of recruitment implementation

- Evaluate the implementation of recruitment

- Evaluate the results of candidates for recruited officers

The policy concept of Navy information service: The improvement of the work performance of the Navy's information service has greatly influenced the achievement of overall organizational goals. This can be seen from the competence of the Navy information service in performing operational, educational and training duties.

Based on the technical guidance manual of the Navy's information service, the officer in the information service community has certain postures. Posture is based on the scope of the task field that must be implemented and adjusted to the posture as a naval officer. which can be spelled out as follows.

Moral in the execution of the task, must have attitudes, behaviors, actions, behavior based on God and the rules that apply. So that, in forming public opinion acceptable to society and environment, either inside or outside of Navy.

Personality is a characteristic that can be demonstrated in good faith as a person of information in the execution of duties and always be well received and open by the environment in charge.

Brave, always have a steady heart and confidence in the face of danger or difficulty in the field of duty. And can pour ideas, suggestions, innovations or ideas relating to improvements in the field of information service both orally and written to the leadership.

Intellectuals have the ability to understand more complex relationships, abstract thinking processes, adapt to an understanding of a problem and the ability to gain and understand quickly new sciences, especially, in the field of information.

The marine technocrat of "Sapta Marga", meaning that the officer is part of the Navy soldiers who are mentally and personally possess the soul of "Sapta Marga" but with the advantages that are always associated with technology and information in accordance with the field of duty.

Imaginative with the characteristics of the task field that is in the scope of information and publications, it must have a high imagination in order to be able to anticipate the possibility that may occur in the future with a good analysis for solving and publication problems that are happening. 
Innovative has the ability to follow the development of technology and the world of information, so, always can know the various information and use it in the execution of the task.

Adaptive is the ability to always be able to contribute and a positive service at every place in charge. Resist the test, as Navy soldiers who work in the Navy information service, should always be mentally high in facing every challenge and obstacle in the completion of the task.

Insightful has an insight into nationality and nationalism, especially, those related to defense and Naval forces in order to provide correct and up to date information in accordance with their field of duty.

There is a standard criterion that must be possessed by the candidate officers and officers who will work on the Navy information service which must be met as follows:

Candidates of officers with the profession of the Navy's information service shall have communication, journalistic, public relations, information, history, cinematography, information and Technology (IT) as well as graphic design qualifications.

Officers who have or are carrying out duties in the information service for a minimum of five consecutive years or in intermittent or non-consecutive periods.

Navy officers who have attended specialist officer's education, such as courses or upgrading related to the field of information such as public affairs, press release, upgrading opinions, upgrading citizen journalism, interviewing and upgrading of historical writing, and attended Bachelor Degree, Master Degree and Doctor Degree in the discipline of science related to information and had served in the information service for at least 5 years.

Criteria mentioned above, at this time, cannot be fulfilled maximally. This is due to the limited personnel who meet all these criteria. Standard competence is needed because the development of information technology and the field of information that is growing rapidly followed by the increasing variety of challenges and problems that arise in the implementation of tasks.

\section{RESULTS AND DISCUSSION}

This study uses an evaluation approach of CIPP Method (Context, input, process and product). The evaluation is based on interview results and secondary data which include:

Context (Background), implementation of recruitment policy officer of Navy information service. Context evaluation of implementing recruitment policy is reviewed from several aspects such as:

\author{
Components of the context aspect \\ Component of context evaluation: \\ - Needs \\ - Problem \\ - Objective
}

Input, implementation of recruitment policy officer of Navy information service. The success of a program requires input. In the context of implementing recruitment policy implementation, the required inputs are:

\section{Components of the input aspect Component of input evaluation: \\ - Human Resources (HR) \\ - Finance \\ - Facility \\ - Readiness}

Process, implementation of the policy program of officer recruitment of information service of the Navy. The process of implementing the recruitment policy of personnel in Navy organization is no exception because the Navy is often in its implementation in the spotlight because the impression that arises is to become the arena of corruption, collusion and nepotism practice. Such an impression will always arise when personnel procurement activities are not conducted in a transparent and accountable manner. So, the principle of openness becomes a very urgent thing that is one point in good governance. The subject matter that is used as the focus in the process stage (process).

\section{Components of the process aspect Component of product evaluation: \\ - Recruitment mechanism \\ - Obstacles}

Product, achievement of policy implementation of recruitment program officer of Navy information service. The achievement of policy implementation of recruitment program officer of Navy information service is the fulfillment of personnel requirement of Navy information service from external recruitment result and internal according to the requirement of Navy information service, so that, it can run Navy information service vision which will finally, give impact to the achievement of Navy Vision. The subject matter that is used as the focus in the stage of achievement (product).

\section{Components of the product aspect Component of product evaluation: \\ - Administrative standards \\ - Competency standards}


Table 1: Congruence analysis of context aspect

The context stage, policy implementation of officer recruitment Description

Assessment

Purpose Empirical data

The need for an optimal recruitment Recruitment can realize the program implementation

Navy information service vision The need to obtain personnel who have the competence of information in order to fill real personnel has not been realized perfectly

Problems in the implementation of recruitment

The objective of holding recruitment
Still in desperate need of coordination on an ongoing basis Requires the understanding of recruitment committees Requires competency standards Still, need to optimize in the implementation of regulation/policy about recruitment

Navy information service work program has not been optimally achieved

\section{Criteria}

The implementation of the recruitment program has not been able to realize the vision of the world-class naval public affairs Navy information service in order to support the creation of the world class navy

Needs of fulfillment real personnel who have the competence of information have not been met

There has not been an integrated coordination between users and recruiters Lack of understanding from the recruitment team

There is no standard of competence for information officers

The need to optimize the implementation of regulations/policies that regulate recruitment

Duplicated work programs are not yet fully operational due to the limited ability of the manning personnel
Decision

Implementing an optimumrecruitment is required to obtain personnel in accordance with the competencies required by Navy information service

Implemented management of of problems that exist

The recruitment goal has not met Navy information service expectations

Table 2: congruence analysis of input aspect

The input stage, policy implementation of officer recruitment Description

Assessment

$\begin{array}{ll}\text { Purpose } & \text { Empirical data } \\ \text { recruitment policy } & \begin{array}{l}\text { Requires a proportional number } \\ \text { of human resources that carry } \\ \text { out the recruitment process } \\ \text { Need an understanding of human } \\ \text { resources recruitment/placement of users } \\ \text { The party responsible for the } \\ \text { recruitment process }\end{array}\end{array}$

$\begin{array}{ll}\text { Criteria } & \text { Decision } \\ \begin{array}{l}\text { Not proportionate to the amount of } \\ \text { recruitment manpower recruited by the } \\ \text { amount recruited, especially in the } \\ \text { external recruitment coming from the } \\ \text { general public }\end{array} & \begin{array}{l}\text { It needs to be more prepared both in } \\ \text { terms of quantity and the ability of } \\ \text { human resources related to the type } \\ \text { of competence that must be understood } \\ \text { by the selection team related to the } \\ \text { needs,generally only carry ing out the } \\ \text { task of carrying out recruitment/selection } \\ \text { in general }\end{array} \\ \begin{array}{l}\text { needs of the user } \\ \text { With limited budget human resources } \\ \text { recruitment must be able to provide } \\ \text { priority scale by sorting competence } \\ \text { needs }\end{array}\end{array}$

its duties optimally by conducting supervision, control and accountability to the central leadership of all duties The limited amount of budget for intemal and external recruitment activities A centralized funding system that has been adjusted to the budget/budgetary terms of the recruitment/placement process Centralized funding sources are made at personnel staff of Naval headquarters for external recruitment and funding at Military Personnel Staff Dept. undertaken by Navy administration personnel service of for internal recruitment

Facility Requires computer network connectivity There are a means of providing initial info on needs/socialization

The absence of connectivity networks between users and recruiters

There has been a means to provide initial info on needs through press socialization/press safari, pamphl, ets., banners, educational exhibitions

It has been prepared its readiness from the administration side The existence of actions in the form of Implementation of administrative readiness (schedule determination making warrant, etc.)

Preparation of recruitment stages (proposals from the work unit, mapping of needs, written rules/conditions on requirements for recruitment/selection/positioning) preparation of recruitment stages for example with the existence of proposing the needs of the work unit, the existence of administrative requirements that must be obeyed by the selection participants in the process of recruitment
Need to be optimized the existence of network connectivity between the users with the implementer for recruitment work can be more effectively efficient

Need more enhanced tidiness from the administrative side of supporting the readiness of recruitment 
Table 3: Congruence analysis of process aspect

The process stage, policy implementation of officer recruitment

Description

Assessment

\begin{tabular}{|c|c|c|c|}
\hline Purpose & Empirical data & Criteria & Decision \\
\hline Recruitment mechanism & $\begin{array}{l}\text { External and intemal recruitment } \\
\text { mechanisms are in compliance with } \\
\text { applicable provisions within Navy } \\
\text { organizations }\end{array}$ & $\begin{array}{l}\text { Mechanisms are in place according to, the } \\
\text { applicable procedures }\end{array}$ & $\begin{array}{l}\text { The mechanism is further enhanced } \\
\text { towardstransparency and accountability }\end{array}$ \\
\hline Obstacles & $\begin{array}{l}\text { Obstacles are encountered not from the } \\
\text { prevailing system but rather from } \\
\text { implementation techniques }\end{array}$ & $\begin{array}{l}\text { The biggest obstacles are lack of communication } \\
\text { between stakeholders and decision makers and } \\
\text { the difficulty of getting candidates with the } \\
\text { qualifications in question and decision makers } \\
\text { and the difficulty of getting candidates with } \\
\text { the qualifications in question }\end{array}$ & $\begin{array}{l}\text { Need more intensified communication } \\
\text { pattern }\end{array}$ \\
\hline
\end{tabular}

Table 4: Congruence analy sis of product aspect

The product stage, policy implementation of officer recruitment Description

Assessment

\begin{tabular}{|c|c|c|c|}
\hline Purpose & Empirical data & Criteria & Decision \\
\hline Administration standards & Fulfillment of administrative standards & $\begin{array}{l}\text { The fulfillment of administrative standards } \\
\text { because there is good supervision by the } \\
\text { extemal recruitment selection committee } \\
\text { and personnel officers for the placement of } \\
\text { positions }\end{array}$ & $\begin{array}{l}\text { Transparency and carefulness in personnel } \\
\text { administration checks should be further } \\
\text { enhanced for compliance with administrative } \\
\text { standards }\end{array}$ \\
\hline Competency standards & $\begin{array}{l}\text { Requires the fulfillment of personal } \\
\text { needs for DSP filling } \\
\text { Requires personnel who have the } \\
\text { required competencies Navy information } \\
\text { service to run the vision and mission } \\
\text { of Navy information service }\end{array}$ & $\begin{array}{l}\text { Internal recruitment is still to fill DSP } \\
\text { without the fulfillment of competence due } \\
\text { to the difficulty of getting personal with } \\
\text { the background in the field of information }\end{array}$ & $\begin{array}{l}\text { Preferably thefilling of thepersonel structural } \\
\text { emptiness after that newly packed various } \\
\text { courses for the addition of self-competence }\end{array}$ \\
\hline
\end{tabular}

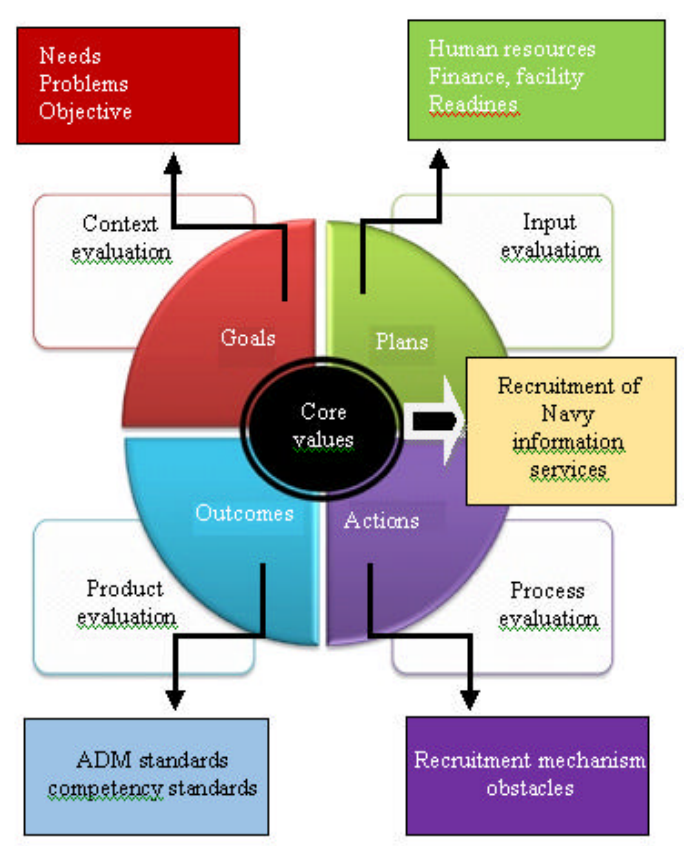

Fig. 3: CIPP evaluation model on recruitment policy officer of Navy information service

\section{CONCLUSION}

Evaluation of the implementation of officer recruitment policy of Navy information service has been done. Based on the results of analysis and discussion, it can be obtained some conclusions as follows:

Needs aspect: Recruitment programs, especially, recruitment of the needs of officers in the work unit Navy information service is a program that is needed. This program is considered as one of the efforts in realizing the vision of a world-class public affairs, so, hopefully with the right recruitment targets will produce officers capable of officers challenge tasks and changes in the sense that the publication activities undertaken personnel Navy information service through any media including the mass media is already global in mind and can have a broad impact on society in general and have a positive impact on the Navy in particular, so as to be able to publish every naval activity in order to create a positive opinion in the community.

Problem aspect: In the implementation of the recruitment program is known to be still encountered many obstacles such as the availability of candidates according to the desired qualifications. Based on data taken from the interview results can be concluded that until now personnel according to the required qualifications are still very difficult to obtain. One of the factors that are considered as the cause is the lack of coordination, so, until now in general, the positioning of officers in Navy 
information service is the only background to occupy vacant position or fulfillment of personnel without followed by competence standard based on qualification of personnel expected in Navy information service.

Objective aspect: The existence of existing recruitment programs to date, especially, for Navy information service based on the results of the interview is not fully realized optimally related to efforts of the world class navy.

Human resources aspects: The existence of human resources in the recruitment program is important in terms of quantity and quality. Based on the results of interviews can be concluded that in terms of quantity/number of personnel involved in the recruitment process can be said that for external recruitment the number of personnel who manned is still lacking, it is seen from the number of personnel in addition to the task and position appointed as the committee of acceptance to the region, thus, also with internal recruitment due to the limited personnel who manned and maneuvered the personnel field.

Related to the quality of human resources in this case, is the level of understanding of tasks in the implementation of recruitment can be concluded still need to be pursued a single vision because it still looks not optimal understanding. This happens because different levels of interest vary in determining the required competencies.

Finance aspects: The budget for the recruitment program based on the interview result can be concluded that the leadership will always try to use the budget effectively and efficiently. Funding that exists within the Navy organization is all done through a programme planning process and of course done in accordance with the provisions of applicable regulations.

Facility aspects: The phenomenon that occurs in the implementation of recruitment, it seems that the facility of computer network connectivity has not been optimally connected with the computer network in Navy Administration of Personnel Service or computer network in Military Personnel Staff Department, so that, often happened delays or difficulty in data transfer. As for the infrastructure facilities provided related to the provision of preliminary information for external recruitment activities has been implemented both in the form of socialization as well as in the form of information dissemination through website, radio, banner installation, pamphlet distribution and educational exhibition to introduce how the education of the Navy through Naval academy education to attract teenagers to register themselves as part of Navy soldiers while for internal recruitment activities have also been conducted through pre-sessions.

The readiness of recruitment aspect: In the recruitment process all administrative phases have been implemented starting from the issuance of the Telegram Warning Letter will be conducted the selection process (recruitment), the preparation of financial accountability, the preparation of the letter of order in the form of work committee and the letter of order execution duties while for internal recruitment has been done sorting internally work unit in the form of needs mapping, submission of proposed placement of personnel in the position, pre-trial activities and the holding of placement positions category.

Recruitment mechanism aspects: The recruitment process is undertaken, so far in both external and internal recruitment processes, the mechanisms undertaken in accordance with applicable procedures within the Navy environment. Constraints faced in this recruitment mechanism is the difficulty of finding candidates who are able to be prepared manned the field of Navy information.

Obstacles aspects: Common obstacles are lack of communication among stakeholders, so that, the required personnel seems difficult to accommodate according to the needs of personnel.

Administrative standards aspects: The process of recruitment specially in the placement of positions, so far it can be said that the internal recruitment process is able to capture personnel based on the fulfillment of administrative standards because it is in place a personnel in a certain position, must first meet the provisions of the initial administration in the form of eligible requirements.

Competency standards aspects: For now it is very difficult to encompass personnel who have educational background of information due to the priority scale that has been determined by Navy Headquarters for external recruitment while for internal recruitment in the form of placement is also constrained from the lack of personnel who have expertise or special competence in the field of information, according to, the current era of openness demands.

\section{ACKNOWLEDGEMENTS}

The researchers greatly acknowledge the support from Study Program of Human Resources Management, Jakarta State University (UNJ Jakarta) and Indonesian 
Navy institution for providing the necessary resources to carry out this research work. The researchers are also grateful to the anonymous reviewers and journal editorial board for their many insightful comments which have significantly improved this study.

\section{REFERENCES}

Ahmadi, A., O.S. Suharyo, K. Susilo and P. Pratisna, 2017. Applied of impressed current cathodic protection design for fuel pipeline network at aaval base. Iran. J. Mater. Sci. Eng., 14: 41-52.

Aldaihani, H.A., K.M. Shuqair, A.M. Alotaibi and S. Alrabah, 2015. Students' perceptions of the effectiveness of the English program taught at the College of Technological Studies in Kuwait. English Lang. Teach., 8: 80-89.

Anyim, F.C., J.O. Ekwoaba and I.D. Anthony, 2012. The role of human resource planning in recruitment and selection process. Br. J. Humanities Soc. Sci., 6: 68-78.

Armstrong, M., 2009. Armstrongs Handbook of Human Resource Management Practice. 11th Edn., Kogan Page, London, UK., ISBN:9780749457389, Pages: 1088.

Bryson, J.M., 1995. Strategic Planning for Public and Nonprofit Organization: A Guide to Strengthening and Sustaining Organizational Achievement. Jossey-Bass, San Francisco, California, USA., ISBN: 9780787901417, Pages: 325.

Fitzpatrick, J.L., J.R. Sanders and B.R. Worthen, 2004. Program Evaluation: Alternative Approaches and Practical Guidelines. 3rd Edn., Pearson Allyn and Bacon, Boston, Massachusetts, USA., ISBN: 9780321077066, Pages: 555.

Hasenfeld, Y., 1983. Human Service Organizations. Prentice Hall, Upper Saddle River, New Jersey, USA., ISBN:9780134474908, Pages: 276.

Kirkpatrick, D.L., 1994. Evaluating Training Programs: The Four Levels. 1st Edn., Berret-Koehler Publishing, San Francisco, California, USA., ISBN: 9781881052494 , Pages: 229.
Sandfort, J., 1999. The structural impediments to human service collaboration: Examining welfare reform at the front lines. Soc. Serv. Rev., 73: 314-339.

Stufflebeam, D.L., 1983. The Cipp Model for Program Evaluation. In: Evaluation Model: Viewpoints on Educational and Human Services Evaluation, Madaus, G.F., M.S. Scriven and D.L. Stufflebeam (Eds.). Kluwer-Nijhoff, Boston, pp: 117-141.

Suharyo O.S., D. Manfaat and H.D. Armono, 2017. Establishing the location of naval base using fuzzy MCDM and covering technique methods: A case study. Intl. J. Oper. Quant. Manage., 23: 61-87.

Thornhill, C., 2009. Local government's contribution to a sustainable developmental state: Opportunities and challenges. Administration Publ., 7: 24-44.

Tiantong, M. and P. Tongchin, 2013. A multiple intelligences supported web-based collaborative learning model using Stufflebeam's CIPP evaluation model. Intl. J. Humanities Soc. Sci., 3: 157-165.

Tsolakis, N. and J.S. Srai, 2017. A system dynamics approach to food security through smallholder farming in the UK. Chem. Eng. Trans., 57: 1-6.

Wei, H.M., L.H. Kuo, H.C. Lin and H.J. Yang, 2011. Evaluating Innovation by CIPP Model. In: Recent Advances in Communications, Circuits and Technological Innovation, Pisarchik, A.N., Y. Shang and C.A. Bulucea (Eds.). WSEAS Press, Paris, France, ISBN:978-1-61804-138-8, pp: 137-142.

Youssefi, H., V.S. Nahaei and J. Nematian, 2011. A new method for modeling system dynamics by fuzzy logic: Modeling of research and development in the national system of innovation. J. Math. Comput. Sci., 2: 88-99.

Zhang, G., N. Zeller, R. Griffith, D. Metcalf and J. Williams et al., 2011. Using the Context, Input, Process and Product evaluation model (CIPP) as a comprehensive framework to guide the planning, implementation and assessment of service-learning programs. J. Higher Educ. Outreach Engagement, 15: 57-84. 